\title{
Ĕgitim Portalları Hakkında Fen Bilimleri Öğretmenleri Ne Düşünüyor?
}

\author{
Doç. Dr. Esma Buluş Kırıkkaya ${ }^{1}$ * \\ İrem Yidırım²
}

Geliş tarihi: 25.02 .2019

Kabul tarihi: 16.03 .2019

\section{Atıf bilgisi:}

Uluslararası Bilimsel

Araştırmalar Dergisi (IBAD)

Cilt: $4 \quad$ Sayı: 2

Sayfa: 222-235 Yll: 2019

Dönem: Yaz

This article was checked by Turnitin. Similarity Index 14\%

\author{
${ }^{1}$ Koaceli Üniversitesi, Türkiye, \\ bulus@kocaeli.edu.tr, \\ ORCID ID 0000-0002-5637-2829 \\ ${ }^{2}$ Türkive, iremvldrm@gmail.com, \\ ORCID ID 0000-0002-9869-1174
}

* Sorumlu yazar

\begin{abstract}
ÖZ
$\mathrm{Bu}$ çalıșma, MEB'e bağlı ortaokullarda görev yapmakta olan fen bilimleri öğretmenlerinin eğitim portalları hakkındaki düşüncelerini araştırmak üzere, öğretmenlerin eğitim portalları hakkındaki bilgileri ve kullanma durumları, hangi eğitim portallarını kullandıkları, eğitim portallarını kullanırken ne tür problemlerle karşılaştıkları ve bu problemlerin giderilmesi için ne gibi çözüm önerilerinin olduğunu, belirlemeyi amaçlayan olgu bilim deseninde nitel bir araştırmadır. $\mathrm{Bu}$ bağlamda çalışma grubunu, Kocaeli İzmit ilçesindeki sekiz ortaokuldaki 26 fen bilimleri öğretmeni oluşturmaktadır. Araştırmanın verileri, yarı yapılandırılmış görüşme tekniği kullanılarak toplanmıştır. Fen bilimleri öğretmenleriyle yapılan görüşmelerden elde edilen veriler içerik analizi yöntemi kullanılarak analiz edilmiştir. Araştırmadan elde edilen bulgulara göre, fen bilimleri öğretmenlerinin derslerinde aktif olarak eğitim portallarından yararlandıkları, EBA, Vitamin ve morpa kampüs portallarını diğer portallara kıyasla daha fazla kullandıkları belirlenmiştir. Bazı öğretmenler portallardaki görsellerin, videoların, interaktif deneylerin ve değerlendirme etkinliklerinin dersi eğlenceli hale getirdiğini ifade ederken bazıları da EBA'nın MEB tarafindan denetlenmesi sebebiyle kullandıklarını ifade etmişlerdir. Yarıdan fazla öğretmenin eTwinning'i daha önce hiç duymadıkları, eTwinning'i duyanların ise bu portalı kullanmadığı, İngilizcelerinin yetersiz olması sebebiyle projelerinin yarım kaldığı belirlenmiştir. Öğretmenlerin portalları kullanırken, MEB'in sunduğu internet altyapısının yetersiz olması, zaman kaybı yaşanması, değerlendirme etkinliklerinin yetersiz olması, takibinin zor olması gibi sorunlarla karşılaştıkları bilgisine ulaşılmıştır.
\end{abstract}

Anahtar Kelimeler: EBA, e-Twining, Vitamin, Fen Bilimleri Öğretmeni 


\title{
What Do Science Teachers Think About Educational Portals?
}

\author{
Assoc. Prof. Dr. Esma Buluş Kırıkkaya ${ }^{1 *}$ \\ Irem Yıdırım²
}

First received: 25.02 .2019

Accepted: 16.03.2019

\section{Citation:}

Journal of the International

Scientific Research (IBAD)

Volume: 4 Issue: 2

Pages: 222-235 Year: 2019

Session: Summer

This article was checked by Turnitin. Similarity Index 14\%

\begin{abstract}
The aim of this study is to investigate the thoughts of teachers about the educational portals and their usage situations about the educational portals of the science teachers working in the secondary schools affiliated to the Ministry of National Education. The phenomenology design which is one of the qualitative research designs has been used in the research. In this context, the study group consists of 26 science teachers in eight secondary schools in Kocaeli. The data of the study were collected by using semi-structured interview technique. Data obtained from interviews with science teachers were analyzed by using content analysis method. According to the findings of the research, it was determined that science teachers used educational portals actively in their lessons and used EBA, Vitamin and morpa campus portals more than other portals. Some teachers stated that the visuals, videos, interactive experiments and evaluation activities in the portals made the lesson fun, while others stated that they used EBA because of the supervision of the MEB. It was determined that more than half of the teachers had never heard of eTwinning, and those who heard about eTwinning did not use this portal and their projects were incompleted due to the lack of English. It has been learned that evaluation activities were inedaquate and the inadequacy of the internet infrastructure provided by MEB has led to a loss of time.
\end{abstract}

Keywords: EBA, e-Twining, Vitamin, Science Teacher

\author{
${ }^{1}$ Koaceli University, Turkey, \\ bulus@kocaeli.edu.tr. \\ ORCID ID 0000-0002-5637-2829 \\ 2Turkey, iremyldrm@gmail.com, \\ ORCID ID 0000-0002-9869-1174
}

* Corresponding Author 


\section{GíRiş}

Ülkemizde elektronik ortamda eğitim veren internet sitelerinin sayısı gün geçtikçe artmaktadır. $\mathrm{Bu}$ durum internet aracılığı ile ulaşılan eğitimin önemini arttırmaktadır. İnternet temelli eğitim veren sitelerde özellikle eğitsel yazılımlar, öğrenme nesneleri ve eğitim portalları öne çıkmaktadır. Ülkemizde de eğitimde kaliteyi artırmak amacıyla çeşitli eğitim portalları bulunmaktadır (Şahin, 2012). EBA eğitim portalı, Vitamin eğitim portalı ve eTwinning eğitim portalı bu portallardan birkaçıdır.

"EBA, gerek öğretmenlerin gerekse öğrencilerin kullanabileceği eğitim araçlarının yanı sıra, eğitsel içeriklerine de yer veren bir ağdır. EBA içerisinde yazı, ses ve resim özelliğindeki kaynakların yanı sıra video anlatımı biçimindeki kaynaklar da yer almaktadır. Dosya yükleme ve dijital alan sağlama, yarışmalar düzenleme, değişik seviyelere uygun dersler, duyurular yapılması ve kullanıcılar tarafindan paylaşımların yapılabilme olanağı EBA sistemini zenginleştiren özelliklerden bazılarıdır" (Aktay ve Keskin, 2016).

Vitamin eğitim portalı, internet üzerinden öğrencilerin kendi öğrenme hızlarına göre istediği zaman erişim sağlayabileceği, Milli Eğitim Bakanlığı (MEB) programlarına uygun olarak hazırlanmış interaktif içeriğe sahip, Web Tabanlı Eğitim yazılımıdır (Şahin, 2012). Özkan ve Öztop, (2016) Vitamin Eğitim Portalı'nın kavramsal öğrenme, problem çözme, görsel ispat, dinamik model, etkileşimli alıştırma türünden beş tür etkinliği kapsayan etkileşimli bir eğitim teknolojisi olduğunu söylemektedir. Ayrıca, Vitamin Eğitim Portalı'nın sağladığı bu zengin içerikle, öğrencilerin derslerini serbestçe takip edebildiği, ögrenilmek istenen konu ile ilgili uygulama ve bilgilere ulaşılabildiği, görerek ve dinleyerek öğrenmeyi kalıcı hale getirebildiği, ders içerisinde geride kaldığı bir konuyu tamamlayıp, öğrenme eksikliklerini de giderebildiği belirtilmektedir.

“eTwinning projesi, kendi web sitesinde Avrupa'daki okulların bir topluluğu olarak tanımlanmaktadır ve Avrupa ülkelerindeki okulların çalışanlarına (öğretmenler, müdürler, kütüphaneciler vb.) iletişim kurmak, iş birliği yapmak, projeler geliştirmek ve paylaşmak için bir platform sağlamaktadır" (Bozdağ, 2017). "eTwinning projelerinde temel olarak iki web platformu kullanılmaktadır. Bunlardan bir tanesi eTwinning ağını ve amaçlarını tanıtan, bitmiş olan ve devam eden projelerle ilgili bilgileri, çevrim içi ve çevrim dışı öğretmen eğitimleri ile ilgili duyuruları içeren eTwinning'in ana sayfasıdır. Öğretmenler buradan devam eden projeleri görebilmekte, projeleri için ortak bulabilmekte ve onlarla iletişime geçebilmektedir. Projeler içinde en az iki farklı ülkeden ortağın olması gerekirken, proje ortak sayısı için bir üst limit belirtilmemektedir. eTwinning çerçevesinde kullanılan ikinci web platformu ise projeler içindeki iletişimin temel kanalı olan Twinspace öğretmenlere kendilerine bir profil sayfası kurma ve bu sayfada kendilerini, ilgi alanlarını ve daha önce yaptıkları projeleri tanıtabilme imkanı sağlamaktadır. Bunun yanında, Twinspace öğretmenlere proje sayfaları geliştirme ve de Twinspace'in sunduğu Wiki, tartışma forumu, chat ve bloglar gibi sosyal medya araçlarını projelerine entegre etme imkanı sağlamaktadır. Öğrenciler de öğretmenleri tarafından bu projelere kaydedilebilmekte ve proje sayfasındaki chat gruplarına, tartışmalara katılıp yazılarını farklı araçlar üzerinden yayınlayabilmektedir" (Bozdağ, 2017).

Alanyazın incelendiğinde EBA ile ilgili yapılmış olan çeşitli çalışmalar bulunmaktadır. Alabay, (2015) tarafindan yapılan çalışmada ortaöğretim öğrencilerinin ve öğretmenlerinin EBA kullanımına ilişkin görüşleri incelenmiştir. EBA'nın öğretmenler tarafından ders işleyiş sürecinde yeterince kullanılmadığı görülmüştür. Güvendi (2014) tarafindan yapılan çalışmada EBA'nın hazırlanan anketle öğretmenlerin yaş, cinsiyet, branş ve çalışılan kurum değişkenine bağlı olarak kullanım sıklığı incelenmiştir. $\mathrm{Bu}$ çalışmanın sonucunda öğretmenlerin EBA eğitim portalını haberleri okumak için kullandıkları, yani öğretmenlerin bilgi paylaşımında kullanmak için tercih etmedikleri görülmüştür.

Tutar (2015)'deki araştırma sonuçlarına göre öğretmenlerin EBA ile ilgili bilgi sahibi olma düzeylerinin düşük olduğu, ayrıca bilgi sahibi olan öğretmenlerin EBA'nın kullanışl1, etkili ve verimli bir site olduğunu düşünmelerine rağmen EBA'yı çok fazla kullanmadıkları görülmüştür. Güvendi (2014)'nin yapmış olduğu araştırma sonuçlarına göre öğretmenlerin EBA'yı kullanım sıklı̆̆ı, olması gerekenin çok altında olduğu ortaya konulmuştur. Yukarıdaki araştırmalar da göstermiştir ki, EBA öğretmen ve öğrenciler tarafından yeterince kullanılmamaktadır (Kapıdere ve Çetinkaya, 2017). 
Alanyazında Vitamin Eğitim Portalı'yla ilgili yapılmış olan çeşitli çalışmalar bulunmaktadır. Özkan ve Öztop (2016) tarafindan yapılan çalışmada lise öğrencilerinin Vitamin eğitim portalı "Lisego" ile ilgili görüşleri incelenmiştir. Öğrenciler; Vitamin Eğitim Portalı'nı kullanma nedenleri olarak, "konu tekrarı ve pekiştirme", "ders çalışmaya yardımcı olma", "derslere ve sinavlara hazırlık", "konuları anlama", "farklı bir öğrenme ortamı" ve "derslerde başarılı olma" şeklinde sıralamışlardır. Bu portalın sayısal derslerde kullanımının uygunluğunu belirten öğrenciler; en çok matematik ve fen derslerinde kullanımının uygun olduğunu, beklentilerini karşılamada ekili olduğunu, derslerde motivasyonlarını artırdığını ve ders başarılarına katkı sağladığını belirtmişlerdir. Parlak (2011) tarafindan yapılan çalışmada öğrenci ve öğretmen görüşlerine göre Vitamin Eğitim Portalı'nın öğrenci başarısını, derse karşı ilgisini, katılımını, motivasyonunu arttırdığı ve dersi eğlenceli hale getirdiği tespit edilmiştir. Fakat öğrenci-öğrenci ve öğrenci-öğretmen etkileşimini azalttığı tespit edilmiştir. Kocaoğlu (2012) tarafından yapılan çalışmada Vitamin Eğitim Portalı kullanılarak işlenen derslerle bu portal kullanılmadan işlenen derslerin öğrenci başarısını ne ölçüde etkilediği araştırılmıştır.

eTwinningle ilgili Bozdağ (2017) tarafindan yapılan bir çalışmada Almanya ve Türkiye'deki okullarda, teknoloji entegrasyonu eTwinning kullanma durumları açısından karşılaştırmalı olarak incelenmiştir. Bozdağ'ın (2017) çalışmasında, eTwinning projesinin uygulanmasında, farklı aşamalarda sorunlar çıkabildiği, okullarda teknolojik altyapı konusunda iyileştirmelere ihtiyaç duyulduğu ve öğretmen eğitimlerinden kısıtlı sayıda öğretmen faydalanabildiği görülmektedir. Ayrıca öğretmen eğitimlerinde teknolojinin geleneksel eğitim yöntemleri ile değil daha katılımcı bir şekilde kullanılması konusu vurgulanmaktadır. eTwinning projelerini gönüllü olarak yürüten ve teknolojiyi bu projeler için aktif olarak kullanan öğretmenlerin çabalarının takdir edilmesi ve ödüllendirilmeleri için daha farklı yöntemler geliştirilmelidir.

EBA, Vitamin ve eTwinning eğitim portalları ile ilgili alanyazın incelendiğinde EBA ve Vitamin eğitim portallarına ilişkin öğrenci ve öğretmen görüşlerinin incelendiği çalışma örnekleri bulunmaktadır. Aktay ve Keskin (2016)'in çalışmasında özellikle öğretmenlerin EBA hakkında yeterli bilgi sahibi olma ve EBA'nın kullanımıyla ilgili sorunlar yaşadıkları görülmüştür. Vitamin Eğitim Portalı ile ilgili Şahin (2012)'in yaptığı çalışmada, çalışmaya katılan öğretmenlerin neredeyse yarısının Vitamin Eğitim Portalı'nı hiç kullanmadıkları ortaya çıkmıştır. Literatür taraması yapılırken EBA, Vitamin ve eTwinning eğitim portallarıyla ilgili fen bilimleri öğretmenlerinin görüşlerinin incelendiği bir araştırmaya ulaşılamamıştır. Özellikle eTwinning eğitim portalı ile ilgili farklı çalışmalara rastlanmaması nedeniyle, yapılan araştırmanın alanyazında dikkat çekeceği ve araştırmacıları eTwinning ile ilgili farklı çalışmalar yapmaya teşvik edeceği düşünülmektedir. EBA ve Vitamin eğitim portallarının öğretmenler tarafindan az da olsa kullanıldığı ve dolayısıyla bu iki portal hakkında fen bilimleri öğretmenlerinin bilgi sahibi olabileceği düşülmektedir. eTwinning ise ülkemizde çok yeni bir eğitim portalıdır ve eTwinning hakkında fen bilimleri öğretmenlerinin görüşleri merak edilmektedir. Bu sebeplerden dolayı belirtilen üç eğitim portalı ile ilgili fen bilimleri öğretmenlerinin görüşlerinin incelenmesine karar verilmiştir. $\mathrm{Bu}$ bağlamda çalışmada EBA, Vitamin ve eTwinning eğitim portallarıyla ilgili fen bilimleri öğretmenlerinin görüşlerinin belirlenmesi amaçlanmaktadır. Bu amaç doğrultusunda aşağıdaki sorulara yanıt aranmıştır.

Fen Bilimleri öğretmenlerinin;

1. Kullandıkları eğitim portalları nelerdir?

2. Eğitim portalları hakkındaki bilgileri ve eğitim portallarını kullanma durumları nelerdir?

3. EBA, Vitamin ve eTwinning eğitim portallarını kullanma nedenleri nelerdir?

4. EBA, Vitamin ve eTwinning eğitim portallarını kullanırken karşılaştıkları problemler nelerdir?

5. EBA, Vitamin ve eTwinning eğitim portallarının içeriği ilgili önerileri nelerdir?

\section{YÖNTEM}

\section{Araştırma Deseni}

$\mathrm{Bu}$ araştırma, Milli Eğitim Bakanlığına bağlı ortaokullarda görev yapmakta olan fen bilimleri öğretmenlerinin hangi eğitim portallarını kullandıklarını, eğitim portalları hakkındaki bilgi düzeylerini ve eğitim portallarını kulanma durumlarını, eğitim portallarını kullanırken ne tür problemlerle karşılaştıkları ve bu problemlerin giderilmesi için ne gibi çözüm önerilerinin olduğunu, belirlemeye yönelik nitel bir çalışmadır. Eğitim portalları gibi öğretmenlere yabancı olmayan aynı zamanda da tam olarak 
algılayamadıkları ya da üzerinde derinlemesine düşünmedikleri bir konu araştırıldığından, araştırma olgu-bilim desenine göre yürütülmüştür.

Olgu-bilim deseni farkında olduğumuz ancak derinlemesine ve ayrıntılı bir anlayışa sahip olmadığımız olgulara odaklanmaktadır. Olgu-bilim çalışmalarında genellikle belli bir olguya ilişkin bireysel algıların veya perspektiflerin ortaya çıkarılması ve yorumlanması amaçlanır (Yıldırım ve Şimşek, 2013).

\section{Çalışma grubu}

Araştırmanın çalışma grubunu, 2017-2018 eğitim-öğretim yılı bahar dönemi Kocaeli Milli Eğitim Müdürlügüne bağlı Kocaeli İzmit ilçesindeki sekiz ortaokuldaki 26 fen bilimleri öğretmeninden oluşmaktadır. Katılımcılar seçilirken amaçlı örnekleme yöntemlerinden ölçüt örnekleme yöntemi tercih edilmiştir. Bu doğrultuda, merkezdeki okullarda çalışan fen bilimleri öğretmenlerinin seçilmesi temel ölçüt olarak belirlenmiştir. Literatürde eğitim portallarıyla ilgili fen bilimleri öğretmenlerinin görüşlerini içeren bir çalışmanın bulunmaması ve fen bilimleri öğretmenlerinin teknoloji alan bilgilerinin daha fazla olması, fen derslerinin içerik olarak eğitim portallarında yer alan animasyon, simülasyon, interaktif deneyler gibi eğitim içeriklerinin kullanıma uygun olması sebebi ile fen bilimleri öğretmenlerinin eğitim portalları hakkındaki görüşleri merak edilmektedir.

\section{Veri toplama aract}

Araştırmanın verileri, yarı yapılandırılmış görüşme tekniği kullanılarak toplanmıştır. Araştırmada fen bilimleri öğretmenlerinin konuya ilişkin görüşlerinin belirlemek üzere araştırmacılar tarafindan 8 sorudan oluşan yarı yapılandırılmış görüşme formu hazırlanmıştır. Yarı yapılandırılmış görüşme tekniğinde, araştırmacı önceden sormayı planladığı soruları içeren görüşme protokolünü hazırlar. Buna karşıı araştırmacı görüşmenin akışına bağlı olarak değişik yan ya da alt sorularla görüşmenin akışını etkileyebilir ve kişinin yanıtlarını açmasını ve ayrıntılandırmasını sağlayabilir (Türnüklü, 2000). Yarı yapılandırılmış görüşme formunda yer alan sorular aşağıda gösterilmiştir.

Görüşme Soruları:

1. Fen eğitimiyle ilgili hatırladığınız herhangi bir eğitim portalı var mı? Varsa paylaşır mısınız?

2. Fen eğitimiyle ilgili aktif olarak kullandığınız bir eğitim portalı var mı? Varsa Söyleyebilir misiniz?

3. Neden bu eğitim portalı/ portallarını kullanıyorsunuz?

4. EBA, Vitamin ve eTwinning kullanıyor musunuz? Kullanmak ister misiniz?

5. Portalları kullanmıyorsanız sebepleri nelerdir?

6. Eğitim portallarını kullanırken ne gibi sorunlarla karşılaşıyorsunuz?

7. Bu sorunların giderilmesi için sizce ne gibi düzenlemeler yapılmalı?

8. Bu portallara neler eklenebilir, önerilerinizi paylaşır mısınız?

\section{Görüşme süreci}

Görüşmelerin öğretmenlerin çalıştıkları ortaokullarda yapılmasına karar verilmiştir, bu konuda katılımcıların onayı alınmıştır. İki araştırmacı ile yapılan çalışmada araştırmacılardan biri öğretmen ile görüşme yaparken diğeri ise ses kayıt cihazının kontrolü ve önemli olan tartışmaların not edilmesi görevini üstlenmiştir.

\section{Verilerin analizi}

Fen bilimleri öğretmenleriyle yapılan görüşmelerden elde edilen veriler içerik analizi yöntemi kullanılarak analiz edilmiştir. İçerik analizi; elde edilen verilerin daha yakından incelenmesine ve bu verileri açıklayan kavram ve temalara ulaşılmasına olanak tanır (Yıldırım ve Şimşek, 2008). Verilerin açık bir biçimde kodlanarak kavramlaştırılması ve belli temalar altında kategorileştirilmesi süreci de denilebilir. Çalışma, kodlama, temaların bulunması, verilerin kodlara ve temalara göre yeniden düzenlenmesi ve bulguların yorumlanması aşamaları dikkate alınarak yürütülmüştür. Analiz sürecinde öncelikle, görüşmeler esnasında alınan notlar ve ses kayıtları çözümlenerek bilgisayar ortamında metin haline getirilmiştir. Görüşme soruları araştırmacılar tarafindan ayrı ayrı kodlanarak temalar oluşturulmuştur. Kullanılan tema ve kodlar tabloya kaydedilip tabloda fen bilimleri öğretmenlerinin görüşleri doğrudan alıntı yapılarak örneklendirilmiştir. Alıntılarda etik açıdan doğru olmayacağı 
düşünülerek katılımcıların isimlerine yer verilmemiştir, onun yerine bulgularda öğretmenlerin görüşleri verilirken öğretmenler 'Ö̈ğretmen1'den “Öğretmen26'ya kadar kodlanmıştır (Akçalı, 2015). Araştırmacılar tarafindan yapılan kodlamalar arasındaki tutarlılı̆̆ belirlemek için Miles ve Huberman (1994) tarafindan önerilen uyuşma yüzdesi formülü kullanılarak hesaplanmış ve \%91 olarak bulunmuştur.

$$
\text { Güvenirlik }=\frac{\text { Görüş Birliği }}{\text { Görüş Birliği }+ \text { Görüş Ayrıllı̆̆ } 1} x 100
$$

\section{BULGULAR}

Araştırmanın bulguları, fen bilimleri öğretmenlerinin eğitim portallarına ilişkin düşüncelerini öğrenmek amacıyla, 26 fen bilimleri öğretmeniyle yapılan yarı yapılandırılmış görüşmelerden elde edilen cevaplardan oluşturulmuştur.

Veri toplama aracının ilk sorusu olan 'Fen eğitimiyle ilgili hatırladığınız herhangi bir eğitim portalı var mı? Varsa paylaşır mısınız?' sorusuna öğretmenlerin verdikleri yanıtlar Tablo1'de verilmiştir.

Tablo 1. Fen öğretmenlerinin 'Fen eğitimiyle ilgili hatırladığınız herhangi bir eğitim portalı var mı? Varsa paylaşır mısınız?' sorusuna verdikleri yanıtların frekans değerleri

\begin{tabular}{lcc}
\hline Yanitlar & f & $\mathbf{\%}$ \\
\hline EBA & 26 & 100 \\
Morpa Kampüs & 23 & 88.4 \\
Vitamin & 15 & 57.7 \\
Okulistik, Bilfen & 5 & 19.2 \\
eTwinning, Fen Okulu & 4 & 15.4 \\
Fatih Gizligider, Fen Sepeti & 3 & 11.5 \\
Twings, Thinkercat Scientix, CroswordPuzzle, Socreative & 1 & 3.8 \\
\hline
\end{tabular}

Tablo 1'deki fen öğretmenlerinin bilgi sahibi oldukları eğitim portallarının frekans değerleri incelendiğinde tüm öğretmenlerin eğitim portallarından haberi olduğu görülmektedir. Öğretmenlerin 26's1 EBA, 23'ü Morpa Kampüs, 15'i Vitamin, 5'i Okulistik ve Bilfen, 4'ü eTwinning ve Fen Okulu, 3'ü Fatih Gizligider ve Fen Sepeti, 1'i Twings, Thinkercat Scientix, Crosword Puzzle ve Socreative eğitim portalı hakkında bilgileri olduğu ifade edilmiştir.

Veri toplama aracının ikinci sorusu olan 'Fen eğitimiyle ilgili aktif olarak kullandığınız bir eğitim portalı varsa söyleyebilir misiniz?' sorusuna verilen yanıtların frekans ve yüzde dağılımı Tablo 2'de yer almaktadır.

Tablo 2. Fen Öğretmenlerinin 'Fen eğitimiyle ilgili aktif olarak kullandığınız bir eğitim portalı varsa söyleyebilir misiniz?' sorusuna verdikleri yanıtların frekans ve yüzde değerleri

\begin{tabular}{lcc}
\hline Yanitlar & f & \% \\
\hline EBA & 24 & 92.3 \\
Morpa kampüs & 12 & 46.2 \\
Vitamin & 4 & 15.4 \\
Bilfen & 3 & 11.5 \\
Fen okulu & 3 & 11.5 \\
\hline
\end{tabular}

Tüm öğretmenlerin aktif olarak kullandıkları bir eğitim portalı olduğu belirlenmiş ayrıca hangi portallar olduğu da Tablo 2'de belirtilmiştir. Bu tabloya göre öğretmenlerin 24'ü EBA, 12'si Morpa Kampüs, 4'ü Vitamin, 3’ü Bilfen ve Fen Okulu eğitim portallarını aktif kullandıkları görülmektedir. 
Fen öğretmenlerinin 'Neden bu eğitim portal1/ portallarını kullanıyorsunuz?' sorusuna verdikleri yanıtların frekans ve yüzde değerleri bulunarak Tablo3'e yerleştirilmiştir.

Tablo 3. Fen öğretmenlerinin 'Neden bu eğitim portal1/ portallarını kullanıyorsunuz?' sorusuna verdikleri yanıtların frekans değerleri

\begin{tabular}{lcc}
\hline Yanıtlar & f & \% \\
\hline İnteraktif Deneyler & 17 & 65.3 \\
\hline Görsellik & 16 & 61.5 \\
Eğlenceli Değerlendirme Etkinlikleri & 11 & 42.3 \\
İlgi Çekici İçerik & 10 & 38.4 \\
Videolar & 7 & 26.9 \\
MEB Denetimi (EBA) & 6 & 23.0 \\
Malzeme Tasarrufu & 6 & 23.0 \\
Ödev (EBA) & 4 & 15.4 \\
Müfredata Uygun İçerik & 4 & 15.4 \\
Güvenli İçerik & 3 & 11.5 \\
Kolay Erişim & 3 & 11.5 \\
Dersi Eğlenceli Hale Getirmesi & 3 & 11.5 \\
Soyut Konuları Somutlaması & 2 & 7.6 \\
BBC Belselleri (Morpa) & 1 & 3.8 \\
\hline
\end{tabular}

Tablo 3'e göre, öğretmenlerin 17'si interaktif deneyler,16's1 görsellik, 11'i eğlenceli değerlendirme etkinlikleri, 10'u ilgi çekici içerik, 7'si videolar, 6's1 EBA'nın MEB tarafından denetlemesi ve deneylerde malzeme tasarrufu sağlaması, 4'ü EBA'da ki ödevler ve müfredata uygun içerik, 3'ü kolay erişim ve dersi eğlenceli hale getirmesi, 2'si soyut konuları somutlaştırması, 1'i Morpa Kampüs'te bulunan $\mathrm{BBC}$ belgeselleri bulunması sebebiyle bu eğitim portalarını kullandıkları cevabını vermiş̧tir Aşağıda bu yanıtları destekleyen bazı öğretmen görüşlerine yer verilmiştir.

Öğretmen4: “İnteraktif videoları seviyorum. EBA'da yalnızca interaktif videoları kullaniyorum. Oradaki yazılı belgelerden, notların hiçbirinden yararlanmıyorum. Zaten yeterince kaynak var bu sebepten EBA'daki notları kullanmayı gerekli bulmuyorum."

Öğretmen7: “EBA, MEB tarafindan kullanılmast isteniyor. MEB, ögretmen ve ögrencilerin ne kadar kullandiğını takip ediyor. Ders anlatımlarının görsel hale getirilmesi, deney, etkinliklerin olması. Her deneyi sinıf ortaminda yapmak mümkün olmuyor."

Öğretmen8: “EBA'yı kullanmamın ana sebebi, MEB'le ortak çalı̧̧ması. MEB her ay ne kadar girdiğimizi soruyor, diğer ögretmenlerle klyasladı̆̆ için kullaniyorum."

Öğretmen15: EBA'da çok fazla işime yarayan bir içerik yok, videoları çocukların ilgisini çekmiyor, etkinlikleri ilgi çekici olmadiğ iç̧in genellikle test ya da boşluk doldurma gibi etkinlikler olduğu için çocuklara sıkıcı geliyor. Ama Morpa Kampüs'te interaktif etkinlikler çocukların daha çok ilgisini çektiği için Morpa'yı daha çok kullaniyorum. Morpa'da BBC'nin belgeselleri çok fazla var. O yüzden çok hoşuma gidiyor. EBA'ya ne kadar girdiğimizi MEB denetlediği için bazı zamanlar dersin başında girdiğim görünsün diye açık bırakıyorum.

Öğretmen26: Morpa'da daha fazla interaktif ĕgitim var ve çocuklar görsel alglyı daha çok seviyorlar. EBA kullanımında zaruret kısmı var çünkü MEB zorunlu tutuyor. EBA'nın bilgi yükü Morpa'ya göre daha fazla. Kendi soru havuzlarımızı oluşturabiliyoruz, ögretmenlerin paylaşımlarından faydalanabiliyoruz.

Veri toplama aracının dördüncü sorusu olan 'EBA, Vitamin ve eTwinning kullanıyor musunuz? Kullanmak ister misiniz?' sorusuna öğretmenlerin 24'ü EBA kullanıyorum, 2'si EBA kullanmıyorum, 19'u Vitamin kullanıyorum, 5'i Vitamin kullanmıyorum, 4'ü eTwinning kullanıyorum, 22'si eTwinning kullanmıyorum, bu eğitim portallarından birini ya da birkaçını kullanmayan 18 öğretmenin bu portalları kullanmak isterim, EBA ve eTwinning kullanmayan bir öğretmenin bu portaları kullanmak istemem, eTwinning kullanmayan bir öğretmenin bu portalı kullanmak istemem, Vitamin ve eTwinning 
kullanmayan bir öğretmenin bu portalları kullanmak istemem cevaplarını vermiştir. Fen öğretmenlerinin cevaplarının frekans değerleri Tablo 4'te belirtilmiştir.

Tablo 4. Fen öğretmenlerinin 'EBA, Vitamin ve eTwinning eğitim portallarını kullanıyor musunuz? Kullanmak ister misiniz?' sorusuna verdikleri yanıtların frekans değerleri

\begin{tabular}{lcc}
\hline Yanitlar & f & \% \\
\hline EBA kullaniyorum & 24 & 92.3 \\
EBA kullanmiyorum & 2 & 7.6 \\
Vitamin kullanıyorum & 19 & 73.1 \\
Vitamin kullanmiyorum & 5 & 19.2 \\
eTwinning kullaniyorum & 4 & 15.4 \\
eTwinning kullanmiyorum & 22 & 84.6 \\
Kullanmak isterim & 18 & 69.2 \\
Kullanmak istemem & 3 & 11.5 \\
\hline
\end{tabular}

Aşağıda Tablo 4'deki yanıtları destekleyen bazı öğretmen görüşlerine yer verilmiştir.

Öğretmen4: “EBA ve Vitamin'i duydum. eTwinning'in eğitim portalı olduğunu bilmiyordum. Ingilizceyle ilgili olduğunu düşündügüm bir etkinlik o kadar."

Öğretmen26: "İki eTwinning projesine başladık fakat ikisinin de sonunu getiremedik. Çünkü, gerekli olan dil desteğini alamadık. Akademik İngilizce gerektirdiği için eksikliğim var. Çok fazla çaba gerektirdiği için bir öğretmenin altından kalkamayacağını düşünüyorum."

Veri toplama aracının beşinci sorusu olan 'Fen eğitimi ile ilgili portalları kullanmıyorsanız sebepleri nelerdir?' sorusuna öğretmenlerin 8'i eTwinning kullanabilmek için İngilizce bilmek gerekiyor, 5'i eTwinning'ten haberim yok, 4'ü zaman yetersizliği, 2'si Vitamin'in ücretli olmas1, 1'i teknolojide kendimi yeterli görmüyorum, 1'i eTwinning projesi hazırlamak yük oluyor ve olumlu dönüt alamıyoruz cevaplarını vermiştir. Fen öğretmenlerinin cevaplarının frekans değerleri Tablo 5 'te belirtilmiştir.

Tablo 5. Fen öğretmenlerinin 'Fen eğitimiyle ilgili portalları kullanmıyorsanız sebepleri nelerdir?' sorusuna verdikleri cevapların frekans değerleri

\begin{tabular}{lcc}
\hline Yanıtlar & f & \% \\
\hline eTwinning kullanabilmek için İngilizce bilmek gerekiyor & 8 & 30.8 \\
eTwinning'ten haberim yok & 5 & 19.2 \\
Zaman yetersizliği & 4 & 15.4 \\
Vitamin'in ücretli olması & 2 & 7.6 \\
Teknolojide kendimi yeterli görmüyorum & 1 & 3.8 \\
eTwinning projesi hazırlamak yük oluyor, olumlu dönüt alamıyoruz & 1 & 3.8 \\
\hline
\end{tabular}

Tablo5'deki yanıtları desteklemek üzere aşağıda bazı öğretmen görüşlerinden doğrudan alıntı yapılmıştır.

Öğretmen3: “eTwinning kullanmıyorum çünkü aynı anda çok fazla portal kullanılamıyor. EBA'da daha fazla etkinlikler var kazanım açısından da EBA'dan gitmek daha kolay oluyor. Sinavlar da bu kazanımlar üzerinden geldiği için daha garanti oluyor. O yüzden diğerlerini daha çok tercih ediyorum." Öğretmen4: "eTwinningle ilgili neredeyse bir bilgim yok. İngilizceyle ilgili olduğunu düşünüyorum sadece. Vitamin' e gerek duymadım. Çünkü, zaten EBA'daki çoğu video Vitamin'den geliyordu önceden, şu anda dikkat etmedim. Bir de Vitamin' in ücretli olduğunu hatırlyyorum."

Öğretmen6: "eTwinning ile ilgili çok fazla bilgim yok bu sebepten kullanmıyorum. Çocuğun derse karşı ilgisini artırmak için sadece bu portallar yeterli değil, çocuk bir süre sonra sıkllyyor ve derse karşı ilgisi dağlliyor."

Öğretmen15: eTwinningte projeler İngilizce yazıldiğg için çok iyi İngilizce bilmek gerektiği için kullanmayl denemedim.

Öğretmen22: "Kendimi proje konusunda yeterli görmüyorum, bu sebepten eTwinning kullanmiyorum. Bu portallar yeterli olduğu için diğerlerine ihtiyaç duymuyorum. Kendimi teknoloji konusunda yeterli görmüyorum." 
Öğretmen23: Kaynak kitapların çok olması sebebiyle portallara çok fazla gerek duymuyorum, nadiren kullaniyorum. Öğretmenler takdir edilmediği için eTwinning gibi portallarda proje hazırlamak bize yük oluyor sadece. Geri dönüt alamıyoruz. Öğretmenlerin desteklenmesi lazım.

Öğretmen24: "İngilizceyi iyi kullanamadığım için eTwinning'te proje yapmaktan çekiniyorum."

Öğretmen25: "eTwinningi dil yetersizliği sebebiyle kullanmiyorum. EBA'yl da derslerde aktif kullanmiyorum çünkü internet okulumuza yeni geldi."

Öğretmen26: "eTwiningi kullanmama sebebi olarak zaman yetersizliği ve dil problemi diyebiliriz."

Veri toplama aracının altıncı sorusu olan 'Eğitim portallarını kullanırken ne gibi sorunlarla karşılaşıyorsunuz?' sorusuna öğretmenlerin 15'i MEB'in sunduğu internet altyapısının yetersiz olmasını, 7'si zaman kaybı yaşanmasını, 5'i EBA'daki değerlendirme etkinliklerinin yetersiz olmasını, 3'ü eTwinning projesi hazırlamak için İngilizce bilmenin gerekliliğini, 2'si EBA'nın güncel olmamasını sorun olarak görürken 2'si sorun yaşamadığını belirtmiştir. EBA'daki yazılımsal sorunlar, yararlı sitelere MEB altyapısında girmenin yasak olması, takibinin zor olması, EBA'daki bazı soruların hatalı olması, öğrencilerin EBA'dan ödev takibi yapmaması ve portallardaki videoların artık günümüz çocuklarının ilgisini çekmemesi yanıtını verenler ise birer kişidir. Fen öğretmenlerinin cevaplarının frekans değerleri Tablo 6'da belirtilmiştir.

Tablo 6. Fen öğretmenlerinin 'Eğitim portallarını kullanırken ne gibi sorunlarla karşılaşıyorsunuz?' sorusuna verdikleri yanıtların frekans değerleri

\begin{tabular}{lcc}
\hline \multicolumn{1}{c}{ Yanıtlar } & $\mathrm{f}$ & $\%$ \\
\hline MEB'in sunduğu internet altyapısını yetersiz buluyorum & 15 & 57.7 \\
Zaman kaybı yaşıorum & 7 & 26.9 \\
EBA'daki değerlendirme etkinliklerini yetersiz buluyorum & 5 & 19.2 \\
eTwinning projesi hazırlamak için İngilizce bilmek gerekli & 3 & 11,5 \\
EBA güncel değil & 2 & 7.6 \\
Sorun yaşamıyorum & 2 & 7.6 \\
EBA'da yazılımsal sorunlarla karşılaşıyorum & 1 & 3.8 \\
Yararlı sitelere MEB altyapısında girmenin yasak olması & 1 & 3.8 \\
Takibinin zor olması & 1 & 3.8 \\
EBA'daki bazı soruların hatalı olması & 1 & 3.8 \\
Öğrencilerin EBA'dan ödev takibi yapmaması & 1 & 3.8 \\
Portallardaki videoların artık günümüz çocuklarının ilgisini çekmemesi & 1 & 3.8 \\
\hline
\end{tabular}

Tablo 6'daki yanıtları desteklemek için bazı öğretmenlerin görüşleri doğrudan verilmiştir.

Öğretmen22: "İnternetle ilgili sorunlarımı oluyor. Siteyi açıp kapayana kadar zaman geçiyor zaman problemleri olabiliyor."

Öğretmen25: "EBA'nın fen alanında çok iyi olmadı̆̆ını düşünüyorum. Video anlatım kısımları ilgi çekici değil. Çocuklara çıktı olarak verebileceğim çok fazla kaynak yok. Derste etkinlikleri açmak için süre harcamam gerekiyor, zaman sikıntısi olabiliyor."

Öğretmen26: "MEB'in sunduğu internet altyapısından dolayı EBA'ya erişimimiz kisitl. Öğrencilerimizin internet erişimleri kısıtlı olduğu için EBA'yl çok aktif kullanamıyoruz. Her portalı kullanmak için zamanımız kısıtll. EBA'nın eski sürümünde öğretmenlere ayrllan kısımda Morpa Kampüs eklentisi vard, ancak MEB tarafindan erişim engelleniyordu. MEB'in internet altyapısi her siteye girmemize izin vermiyor. Yararlı sitelere giremiyoruz, ancak MEB şöyle bir imkan tanımış bu sitenin güvenli olduğunu düşünüyorsanı bize bildirebilirsiniz diye bildirdiğiniz takdirde süreç hızlı işlemiyor. EBA'nın içerik kategorileşmesini beğenmiyorum, ön planda okullardan gelen haberler var. Gönderilen video ve sesler çok fazla süzülmüyor. Çekim ve ses kalitesi verdiği bilgilendirme açısından baktı̆̆ımızda paylaşımlar verimli gelmiyor. Yaptı̆̆ımız paylaşımlarda MEB sizi sorumlu tutuyor telif konusunda."

Veri toplama aracının yedinci sorusu olan 'Bu sorunların giderilmesi için sizce ne gibi düzenlemeler yapılmalı?' sorusuna öğretmenlerin 6'sı internet altyapısı düzenlenmeli, 3'ü de EBA'daki sorular öğrenci seviyesine uygun olmalı yanıtını vermişlerdir. EBA için soru hazırlama komisyonu kurulmalı, her sınıfta akıllı tahta olmalı, EBA için videoların içeriği geliştirilmeli, öğrencilerin aktif katılımının olduğu bir 
sistem kurulmalı, MEB denetlemesi düzenlenmeli, EBA'nın içeriğindeki karışıklık düzenlenmeli, sorular güncel olmalı, okullardaki bilişim öğretmeni sayısı artırılmalı ve internet kısıtlanması düzenlenmeli yanıtlarını ise birer kişi desteklemektedir. Fen öğretmenlerinin cevaplarının frekans değerleri Tablo 7'de belirtilmiştir.

Tablo 7. Fen öğretmenlerinin ' Bu sorunların giderilmesi için sizce ne gibi düzenlemeler yapılmalı?' sorusuna verdikleri yanıtların frekans değerleri

\begin{tabular}{lcc}
\hline Yanıtlar & f & \% \\
\hline İnternet altyapısı düzenlenmeli & 6 & 23.0 \\
EBA'daki sorular öğrenci seviyesine uygun olmalı & 3 & 11,5 \\
EBA için soru hazırlama komisyonu kurulmalı & 1 & 3.8 \\
Her sınıfta akı1lı tahta olmalı & 1 & 3.8 \\
EBA için videoların içeriği geliştirilmeli & 1 & 3.8 \\
Öğrencilerin aktif katılımının olduğu bir sistem kurulmalı & 1 & 3.8 \\
MEB denetlemesi düzenlenmeli & 1 & 3.8 \\
EBA’nın içeriğindeki karışıklık düzenlenmeli & 1 & 3.8 \\
Sorular güncel olmalı & 1 & 3.8 \\
Okullardaki biliş̧im öğretmeni sayısı artırılmalı & 1 & 3.8 \\
İnternet kısıtlanması düzenlenmeli & 1 & 3.8 \\
\hline
\end{tabular}

Tablo 7'deki yanıtları destekleyecek öğretmen görüşlerden birkaçı aşağıda verilmiştir.

Öğretmen10: "Dağıtılan tablet bilgisayarları keșke sınıfta aktif kullanabilsek, bir tane program var soru yazıp yüklüyorsunuz bütün katılımcllar bağlanıyor o ă̆a her ögrenci kendine bir isim yazlyor, hangi öğrencinin hangi soruya cevap verdiğini, hem öğrenciler aynı anda kaçıncı oldukların görebiliyorlar. Bu sistem kurulabilse çok iyi olur."

Öğretmen12: “EBA'y öğretmen derste aktif kullanmasa bile MEB tarafindan denetlendiği için açık bırakabiliyor, aslında ögretmen burada kendini ekarte ediyor. Bu konuda düzenlemeler yapılabilir."

Öğretmen14: "Bence EBA daha planlı olmalı bana çok karışık geliyor. EBA'da karmaşayı giderebilmek için bir düzenleme istiyorum. Girdiğimiz bir videonun izlendiğine dair yanında bir bilgi olsa böylece hangi videoyu izleyip izlemediğimi ayırt edebilirim."

Öğretmen26: "Bilişim ve formatör öğretmenlerin sayısı artırılmalı. Teknoloji konusunda kendini gelişstirmek isteyen ögretmenlere daha fazla kurs düzenlenebilir. EBA'nın işleyişinden sorumlu olan MEB kısımlarının bürokrasiden bağımsı olarak kendilerini geliştirmeleri ve hızlanmaları, internetin kontrolünün biraz daha serbest burakılmasl, örneğin interneti sayfa olarak değil de içerik olarak incelemek bizim için daha yararl. Sansürün içerik olarak uygulanması bana daha mantıklı geliyor. Youtube çok önemli bir kaynak, maalesef bunu akıllı tahtada kullanamıyoruz. Yapılan sansür uygulamalarının sayfa bazında olması bizim için daha kaliteli içerik bulmayı sağlayacaktır. Bunun yanı sira çok fazla elektronik ve tablet eğitiminin kullanılması doğru bulmuyorum, öğrencileri hantallaştırdığını düşünüyorum. Eğitimin çok fazla interaktifliğe ve hazır bilgiye dayalı olmasını doğru bulmuyorum."

Veri toplama aracinın sekizinci ve son sorusu olan 'Bu portallara neler eklenmeli?' sorusuna öğretmenlerin 8'i interaktif deneylerin, 7'si oyunlaştırılmış değerlendirme etkinliklerinin, 6's1 EBA'ya daha fazla sorunun, 5'i EBA'ya belgesellerin eklenmesini isterken 4'ü fikrim yok yanıtını vermiştir. 2 kişi canlı etkileşimin olduğu bir sistemi ve 2 kişi de EBA'ya Youtube bağlantısı eklenmesini istemiştir. Açık uçlu sorular, etkileşimli kitap, EBA'ya sanal gerçeklik, yarışmacı bir sistem, EBA'ya bunları biliyor musunuz? Köşesi ve sanal laboratuvar eklenmesini isteyenler ise birer kişidir. Fen ögretmenlerinin cevaplarının frekans ve yüzde değerleri Tablo 8'te belirtilmiştir. 
Tablo 8.

Fen öğretmenlerinin ‘ Bu portallara neler eklenmeli?' sorusuna verilen yanıtların frekans değerleri

\begin{tabular}{llc}
\hline Yanıtlar & $\mathbf{f}$ & $\mathbf{\%}$ \\
\hline Interaktif deneyler & 8 & 30.8 \\
Oyunlatırılmış değerlendirme etkinlikleri & 7 & 26.9 \\
EBA'ya daha fazla soru eklenmeli & 6 & 23.0 \\
EBA'ya belgeseller eklenmeli & 5 & 19.2 \\
Fikrim yok & 4 & 15.4 \\
Canlı etkileşimin olduğu bir sistem & 2 & 7.6 \\
EBA'ya Youtube bağlantıs1 & 2 & 7.6 \\
Açı uçlu sorular eklenmeli & 1 & 3.8 \\
Etkileşimli kitap & 1 & 3.8 \\
EBA'ya sanal gerçeklik & 1 & 3.8 \\
Yarışmacı bir sistem & 1 & 3.8 \\
EBA'ya bunları biliyor musunuz? Köşesi & 1 & 3.8 \\
Sanal laboratuvar eklenmeli & 1 & 3.8 \\
\hline
\end{tabular}

Tablo 8'deki yanıtları destekleyecek öğretmen görüşlerden bir kaçı aşağıda verilmiştir.

Öğretmen15: “BBC ya da TRT'nin belgeselleri EBA'ya yüklenebilir. EBA'nın Youtube ile bağlantısı olmasi gerekiyor, okulun interneti Youtube girmiyor ama işe yarayacak birçok video Youtube'da oluyor, okulda açamıyoruz. En azından devletin desteklediği belli sinırlar içinde EBA'da Youtube eklentisi olabilir. EBA'ya daha farklı konsepte videolar yüklenebilir, açık uçlu sorular geliştirilebilir örneğin sınavlarda açık uçlu sorulacak ancak EBA'da bu tür sorular yer almıyor. Genellikle soruları test mantığında. Sirf MEB desteklediği sinava yönelik alıştırmalar olması gerekmiyor. Daha farklı tarzda sorular olabilir."

Öğretmen23: "Çocukları motive edecek yarışmacı bir sistem olabilir. Şu etkinlikleri tamamlayana hediye, gezi gibi hediyeler verilmeli. EBA'daki soru çeşitleri arttırllabilir. Kaynak kitap olarak ben $E B A ' y$ önerebilirim. Soruların zorluk seviyesi artırlabilir. Sorular zorluk derecelerine göre siralanmalı (1,2,3 düşük seviye 4,5,6 orta seviye gibi...)."

Öğretmen26: "MEB, Youtube üzerinde kanal açabilir. Öğretmenlerin bu kanala gönderdiği videoları bu kanal üzerinde toplayabilirler ve sadece bu kanala erişimimiz olabilir. EBA'da günlük bilgilerin yer aldı̆̆ı "bunları biliyor musunuz?” Köşesi olabilir. Çünkü günlük hayattan hikayeler öğrencilerin ilgisini çekiyor. Deneyleri yapamayan, laboratuvar olmayan çok okul var flash animasyonlarla bu deneylerin sanal ortamda nasıl gerçekleştiğini gösteren bir ortam oluşturulabilir. EBA'da sanal laboratuvar var ancak kisitl sadece lise ögrencilerine yönelik. EBA'nın değerlendirme etkinlikleri bilgi düzeyinde, değerlendirme çocuğun kavrama ve yorumlama yeteneklerini ölçmek zorunda. Şuanki sinav siteminde ise soru tipleri yorulama düzeyinde bizim öğrencilerimiz bilgi düzeyinde soruları alıyorlar ancak bunları yorumlamaya çeviremediklerinden yeterli bulmuyorum. EBA'daki sorular daha çok mantık soruları formatına çevrilebilir. Bu da öğrencileri farklı kaynaklara yönlendiriyor, ailelerine ekonomik olarak yük oluyor."

\section{SONUÇLAR}

Fen bilimleri öğretmenlerinin, EBA, Vitamin ve eTwinning eğitim portalları hakkında görüş ve düşüncelerinin araştırıldığı bu çalışmanın sonuçları şunlardır:

1. Fen öğretmenleri eğitim portallarından haberdar olduklarını ve derslerinde aktif olarak portaları kullandıklarını belirtmişlerdir. Öğretmenlerin EBA ve Morpa Kampüs portallarını diğer portallara göre daha çok beğendikleri ve derslerinde daha fazla kullandıkları sonucuna ulaşılmıştır.

2. Öğretmenlerin büyük bir çoğunluğu bu portalları kullanma sebepleri olarak portallarda bulunan interaktif deneylerin ilgi çekici olduğunu, sınıfta yapılması tehlikeli olan deneylerin portallardaki interaktif deneyler sayesinde rahatça yapılabildiği, ayrıca interaktif deneylerin malzeme israfinın 
da önüne geçtiğini, görsel içeriğin öğrencilerin dikkatini çektiğini, eğlenceli değerlendirme etkinlikleri sayesinde öğrencilerin soruları çözmeye daha istekli olduklarını belirtmişlerdir.

3. Öğretmenlerin Morpa Kampüsteki videoları, görsel içerikleri ve interaktif deneyleri EBA’ya göre daha çok beğendikleri, EBA'daki içeriğin Morpa Kampüs'te olduğu gibi daha ilgi çekici hale getirilmesini istedikleri sonucuna ulaşılmıştır.

4. Öğretmenlerin EBA'ya girişlerinde MEB denetiminin büyük bir etken olduğu, hatta öğretmenlerin bazıları EBA'ya giriş yaptıklarını ancak derslerinde EBA'yı aktif kullanmadıklarını belirtmiş̧lerdir. Bu çalışmanın en ilgi çekici sonucudur ve öğretmenler bu konuda düzenleme yapılmasını istemektedirler.

5. Öğretmenlerin büyük bir çoğunluğu EBA ve Vitamin portallarını kullanmaktadır, ancak eTwinning portalını kullanmadıkları fark edilmiştir. Öğretmenlerin eTwinning'i kullanmamalarının temel nedeni İngilizcelerinin yetersiz olmasıdır. eTwinning'ten haberdar olmamaları, zaman yetersizliği, proje hazırlarken beklenilen olumlu dönütlerinin alınamaması sonucu öğretmenlerin proje hazırlamayı yük olarak görmeleri, teknolojide kendilerini yeterli görmemeleri eTwinning kullanmamalarının diğer sebepleridir.

6. Öğretmenlerin büyük çoğunluğu eğitim portallarını kullanırken MEB'in sunduğu internet alt yapısının yetersiz olması ve internet kaynaklı bir sorunun ders anında zaman kaybına sebep olması gibi sorunlarla karşılaştıklarını belirtmişlerdir.

7. Öğretmenlerin, internet altyapısının düzenlenmesi, EBA'daki soruların öğrenci seviyesine uygun olması, EBA'daki görsel ve video içeriklerinin geliştirilmesi, öğrencilerin aktif katılımlarının olduğu bir sistemin kurulması, EBA'ya uygulanan MEB denetiminin düzenlenmesi, internet kısıtlamasının düzenlenmesi gibi bu portallardaki sorunlara çözüm önerilerinde bulundukları sonucuna ulaşılmıştır.

8. Öğretmenlerin büyük çoğunluğu özellikle EBA'daki interaktif deneylerin sayısının artırılması, oyunlaştırılmış değerlendirme etkinliklerin eklenmesi, EBA'ya daha fazla öğrenci seviyesine uygun soru eklenmesi gerektiğini belirtmişlerdir.

9. Fen öğretmenleri eğitim portallarını kullanma sebeplerinden biri interaktif deneylerin ilgi çekici olmasıdır, ancak eğitim portallarına interaktif deneylerin eklenmesini istemeleri öğretmenlerin de bu portalları aktif kullanmadıklarını göstermektedir. Öğretmenlerin belirli bir süre bu portalları kullanmaları sağlanıp daha sonra bu portallar hakkındaki görüşlerinin analiz edilmesi daha sağliklı olacaktır.

\section{TARTIŞMA}

Bu çalışmada öğretmenler eğitim portallarını kullanırken MEB'in sunduğu altyapının yetersiz olduğu ve bu konuda iyileştirme yapılması gerektiğini, Vitamin ve Morpa Kampüs gibi eğitim portallarına bu portalların ücretli olması ve internet sorunları sebebiyle öğrencilerin evlerinde giremediklerini belirtmiştir. Şahin (2012)'in Vitamin Eğitim Portalı hakkında öğretmen görüşlerinin alındığı çalışmada öğretmenler altyapıda sorunlar yaşadıkları ve bu sebepten portalları kullanmadıklarını, eğitimde firsat eşitliğinin tam olarak sağlanması için MEB tarafından Vitamin Eğitim Portalı'na öğrencilerin okul dışından da ücretsiz erişim imkânı sağlanmasının gerekli olduğunu bildirmişlerdir. Bu sonuç yapılan çalışma ile benzerlik göstermektedir. Tablo 3'te Neden eğitim portallarını kullanıyorsunuz? Sorusuna fen öğretmenleri portallardaki interaktif deneyler, görseller, videolar'ın dersi ilgi çekici hale getirdiği görüşünü belirtmişlerdir. Güvendi (2014)'nin yapmış olduğu çalışmada da EBA'nın öğretmenlerce kullanım sıklığının belirlendiği çalışmada öğretmenler, EBA'da bulunan eğitsel e-içeriklerden faydalanmak için bu portalı kullandıklarını belirtmişlerdir.

Elde edilen bulgular sonucunda fen öğretmenleri en çok EBA, Morpa Kampüs ve Vitamin eğitim portallarını kullandıklarını, portallardaki görsel içerik sayesinde öğrencilerin derse karşı ilgisinin arttığını, en çok internet alt yapısından kaynaklı sorunlar yaşadıklarını, portalların içeriğinin öğretim programıla tutarlı olması gerektiğini ve bazı fen öğretmenleri teknoloji konusunda kendilerini yeterli bulmadıklarını belirtmişlerdir. Güler, Kaya ve Uzun (2014)'un yapmış olduğu fen bilimleri 
öğretmenlerinin internet kullanımına ilişkin görüşlerinin incelendiği çalışmada benzer sonuçlara ulaşılmıştır.

Elde edilen bulgular sonucunda fen öğretmenleri EBA'yı ilgi çekici görsel içerik ve değerlendirme etkinleri sebebiyle kullandıklarını belirtmişlerdir. Alabay (2015)'in yapmış olduğu öğretmen ve öğrencilerin EBA kullanımına ilişkin görüşleri üzerine çalışmada, öğretmenlerin EBA'da en çok tercih edilen içeklerin test soruları, görsel ve işitsel materyaller olduğu sonucuna ulaşılmıştır. Ancak Alabay (2015)'in yapmış olduğu çalışmada öğretmenlerin EBA'da en az tercih ettikleri içeriklerin eğitsel oyun ve deney uygulamaları olduğu görülmektedir. Bizim çalışmamızda bu sonucun tam aksi sonuca ulaşılmıştır. Fen öğretmenleri EBA'daki interaktif deneyleri ve eğitsel oyunlarında derslerinde aktif kullandıklarını belirtmişlerdir. Bunun sebebi fen derslerinin deney ve eğitsel oyun tasarımına uygun içerikler içermesinden kaynaklanabilir.

\section{ÖNERILER}

Her ne kadar nitel bir araştırmanın sonuçlarının genellenemeyeceği ve o yüzden bu sonuçlara bakılarak öneri getirmenin tartışma yaratması ihtimali olsa da doğrudan sorunun bir parçası olan öğretmenlerin yapmış olduğu öneriler ışığında birkaç öneri yapmak yararlı olabilir. EBA eğitim portalının içeriğinin daha güncel hale getirilmesi, soruların içeriğinin öğrenci seviyelerine uygun hazırlanması, EBA'daki sorularda yeni sınav sistemine uygun hazırlanması, günümüz teknolojilerden sanal gerçeklik, web 2.0 araçları, Youtube bağlantılarının EBA'ya eklenmesi, okullardaki internet altyapısının düzenlenmesiyle ilgili çalışmaların yapılması bu önerilerden bir kaçıdır. Youtube öğretmenler için çok önemli bir kaynak olabilecekken, sansür uygulamasından dolayı akıllı tahtalarda açılamadığı öğretmen görüşleri arasındadır. Bu sorunu önlemek için MEB, Youtube üzerinde kanal açabilir. Öğretmenlerin bu kanala gönderdiği videoları kanal üzerinde toplayabilir ve öğretmenlerin sadece bu kanala erişimi olabilir. Öğretmenlerin çoğunun eTwinning portalı hakkında yetersiz bilgiye sahip olduğu araştırmanın sonuçları arasında yer almıştır, bu konuda MEB eTwinningle ilgili uygulamalı eğitimleri yaygınlaştırabilir. $\mathrm{Bu}$ çalışma sadece 26 fen bilimleri öğretmeninin görüşlerinden elde edilen sonuçlar ile sınırlıdır. Hem ögrencilerin eğitim portallan hakkındaki görüşleri hem de hem de diğer branş derslerinde eğitim portallarının kullanımına yönelik öğretmen görüşleri bir başka çalışmada ele alınabilir.

Bilgilendirme / Acknowledgement: Bu çalı̧ma 13. Ulusal Fen Bilimleri ve Matematik Eğitimi Kongresi’nde sözlü bildiri olarak sunulmuş̧ur.

\section{KAYNAKÇA}

Akçalı. A. A. (2015). Kuram ve uygulamada sınıf dışı tarih öğretimi algısı: Öğretmen ve aday öğretmen görüşleri. Eğitim ve Bilim, 40(181), 117-137.

Aktay, S., ve Keskin, T. (2016). Eğitim Bilişim Ağı (EBA) incelemesi. Eğitim Kuram ve Uygulama Araştırmaları Dergisi, 2(3), 27-44.

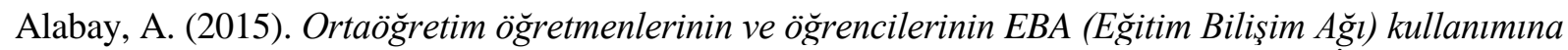
ilişkin görüşleri üzerine bir araştırma. Yayımlanmamış yüksek lisans tezi, İstanbul Aydın Üniversitesi, İstanbul.

Bolat, Y. (2016). Ters yüz edilmişs sınıflar ve Eğitim Bilişim Ağı. Journal Of Human Sciences, 13(2), 3373-3388.

Bozdağ, Ç. (2017). Almanya ve Türkiye'de okullarda teknoloji entegrasyonu: eTwinning örneği üzerine karş1latırmalı bir inceleme. Ege Eğitim Teknolojileri Dergisi, 1(1), $42-64$.

Buluş Kırıkkaya, E., Bozkurt, E., ve Öztürk, N. (2012). Fen ve teknoloji öğretmenleri eğitim araştırmaları ile ilgili ne düşünüyor? Çağdaş Eğitim Dergisi, 1, 63-75.

EBA. (2017). 10 Şubat 2018 tarihinde http://www.eba.gov.tr adresinden erişildi.

eTwinning. (2017). 10 Şubat 2018 tarihinde http://www.etwinning.net adresinden erişildi. 
Demirci G., M. P., Kaya, S., ve Uzun, A. (2014). Fen bilimleri öğretmenlerinin öğretimde internet kullanımına ilişkin görüşleri: Kırşehir ili örneği. Journal of Kirsehir Education Faculty, 15(1), 263-280.

Güvendi, G. (2014). Milli Eğitim Bakanlı̆̆ının öğretmenlere sunmuş olduğu çevrimiçi eğitim ve paylaşım sitelerinin ögretmenlerce kullanım sıklı̆ı̆nın belirlenmesi: Eğitim Bilişim Ağı örneği. Yayımlanmamış yüksek lisans tezi, Sakarya Üniversitesi, Sakarya.

Kapıdere, M., ve Çetinkaya, N. (2017). Eğitim Bilişim Ağı (EBA) mobil uygulamasının değerlendirilmesi. IJAL, 1-14.

Kocaoğlu, G. A. (2012, Temmuz). Web tabanl yazllım olan Vitamin programinın öğrencilerin fen ve teknoloji dersindeki başarılarına ve tutumlarına etkisi. Yayımlanmamış yüksek lisans tezi, Çanakkale Onsekiz Mart Üniversitesi, Çanakkale.

Matthew, B. M., and Huberman, A. (1994). Qualitative data analysis: An expanded sourcebook. 2nd ed. USA: Sage Publications.

Özkan, H. ve Öztop, M. (2016). Öğrencilerin Vitamin eğitim yazılımıyla ilgili görüşlerinin analizi: Yeni Levent Lisesi ve Etiler Lisesi örneği. Süleyman Demirel Üniversitesi Sosyal Bilimler Entitüsü Dergisi, 1(23), 177-196.

Pala, F., Arslan, H., ve Özdinç, F. (2016). Eğitim Bilişim Ağı web sitesinin otantik görevler ve göz izleme ile kullanılabilirliğinin incelenmesi. Ihlara Eğitim Araştırmaları Dergisi, 2(1), 24-38.

Parlak, i. (2011). Illkögretimde uygulanmaya başlanan web destekli MEB Vitamin eğitim yazllımının ögrenci ve ögretmen görüşleri doğrultusunda değerlendirilmesi. Yayımlanmamış yüksek lisans tezi, Marmara Üniversitesi, İstanbul.

Şahin, Ö. (2012, Ocak). MEB Vitamin ilkögrretim portalı hakkındaki ögretmen görüşlerinin ve öğrenci tutumlarının incelenmesi. Yayımlanmamış yüksek lisans tezi, Gaziantep Üniversitesi, Gaziantep.

Tutar, M. (2015). Eğitim biliş̧im ă̆ (EBA) sitesine yönelik olarak öğretmenlerin görüşlerinin değerlendirilmesi. Yayımlanmamış yüksek lisans tezi, Karadeniz Teknik Üniversitesi, Trabzon.

Türnüklü, A. (2000). Eğitim bilim araştırmalarında etkin olarak kullanılabilecek nitel bir araştırma tekniği: görüşme. Kuram ve Uygulamda Eğitim Yönetimi Dergisi, 24(24), 543-559.

Yildırım, N. (2013). Ortaokul 5. sinıf fen ve teknoloji dersinde kullanılan MEB Vitamin eğitim yazılımının ögrencilerin yansitıcı düşünme becerilerine ve erişilerine etkisinin incelenmesi. Yayımlanmamış yüksek lisans tezi, Konya Necmettin Erbakan Üniversitesi, Konya.

Yıldırım, A., ve Şimşek, H. (2008). Sosyal Bilimlerde Nitel Araştırma Yöntemleri. 6. Baskı. Ankara: Seçkin.

Yücel, H. (2011). Illköğretim matemetik eğitiminde web destekli "MEB Vitamin" adlı öğretim materyaline ilişkin ögrretmen görüşleri. Yayımlanmamış yüksek lisans tezi, Yüzüncüyıl Üniversitesi Fen Bilimleri Enstitüsü, Van. 